\title{
Identification of Suitable Varieties of Soybean for Various Soil Types in Different Climatic Conditions
}

\author{
K. S. Baig ${ }^{1 *}$,D. G. More ${ }^{1}$ and A. D. Pandagale ${ }^{2}$ \\ ${ }^{1}$ All India Coordinated Research Project on Soybean, ${ }^{2}$ Cotton Research Station, Nanded, \\ Vasantrao Naik Marathwada Krishi Vidyapeeth, Parbhani, Maharashtra, India \\ *Corresponding author
}

Keywords

Soybean, Climate,

Seed yield, Soil type

\section{Article Info}

Accepted:

15 September 2020 Available Online: 10 October 2020

\section{A B S T R A C T}

In the present investigation, effort has been made to identify most suitable variety of soybean in light, medium and heavy soils under different climatic conditions by conducting experiment in three State Agricultural Universities jurisdiction of Maharashtra (Vasantrao Naik Marathwada Agricultural University, Parbhani, Mahatma Phule Agricultural University , Rahuri and Dr.Panjabrao Deshmukh Agricultural University,Akola) at three locations viz,.Parbhani, Amravati and Jalgaon during the year 2007-2008 to 2009-2010 on three different soil types viz.,light, medium and heavy soils at each location with eight soybean varieties viz., TAMS 38, TAMS 98-21, MAUS 71, MAUS 47, MAUS 32, DS 228, MACS 450 and JS 335. On an average of three years data (2007-2008 to 2009-2010), the variety TAMS 98-21 ranked first in light and heavy soil, whereas, the variety MAUS 71 ranked first in medium type of soil. On an average of twenty seven trials conducted during three years in light, medium and heavy soil at the same location across the soil types, the variety MAUS 71 ranked first $(1881 \mathrm{~kg} / \mathrm{ha})$ followed by TAMS 98-21 (1872 kg/ha). The yield levels of JS $335(1816 \mathrm{~kg} / \mathrm{ha})$ and MACS $450(1813 \mathrm{~kg} / \mathrm{ha})$ were found almost at par.

\section{Introduction}

Soybean has been now established as oilseed as well as pulse crop. It was emerged as cheapest alternate source of high quality protein food and edible oil (Agarwal et al., 2010). It is a triple beneficiary crop, which contains about 20 percent of oil which is high in essential fatty acids (Omega-6 and Omega3 ) and 38 to 42 percent high quality protein with 6.4 percent lysine (Samra and Ramchandra, 2009). In India, the area and production of soybean has extensively increased up to 10.7 million hectare during 2012 (Anonymous, 2012). Unfortunately there has been no significant increase in the productivity. As compared to the productivity of United States of America, Brazil, Argentina and China, India's productivity is still very low. Soybean need a soil that is warm, moist, well supplied with air and provides good contact between the seed and soil for rapid germination (Hans et al, 1997). However, area under soybean has been 
increased to more than 32 lakh hectares irrespective to ideal soil type and suitable variety resulting in poor average productivity, which remains constant around 10 to 12 quintals since last 25 years in Maharashtra (Anonymous, 2005). Therefore, effort has been made to identify most suitable variety of soybean in light, medium and heavy soils under different climatic conditions by conducting experiment in three State Agricultural Universities jurisdiction of Maharashtra.

\section{Materials and Methods}

An experiment was conducted in three State Agricultural Universities jurisdiction of Maharashtra (Vasantrao Naik Marathwada Agricultural University, Parbhani, Mahatma Phule Agricultural University, Rahuri and Dr. Panjabrao Deshmukh Agricultural University, Akola) at three locations viz., Parbhani, Amravati and Jalgaon during the year 20072008 to $2009-2010$ on three different soil types viz., light, medium and heavy soils at each location with eight soybean varieties viz., TAMS 38, TAMS 98-21, MAUS 71, MAUS 47, MAUS 32, DS 228, MACS 450 and JS 335. The experiment was conducted in Randomized Block Design. The gross and net plot size was $3.60 \times 5.00 \mathrm{~m}^{2}$ and $2.70 \times 4.50$ $\mathrm{m}^{2}$, respectively. Recommended fertilizer dose (30:60:30:20 NPK and S kg/ha) and plant protection schedule was followed during the period of investigation.

\section{Results and Discussion}

In light soil type, on an average of three trials conducted during 2007 to 2009 at Parbhani, the variety JS 335 recorded highest seed yield (2094 kg/ha), whereas the varieties viz., MAUS 32 (1554 kg/ha) and TAMS 98-21 $(2107 \mathrm{~kg} / \mathrm{ha})$ ranked first at Amrawati and Jalgaon location, respectively. On pooled basis, on an average of nine trials, the variety TAMS 98-21 (1717 kg/ha) ranked first followed by MACS 450 and MAUS 71 (both $1686 \mathrm{~kg} / \mathrm{ha}$ ) (Table 1).

Table.1 Pooled analysis of seed yield ( $\mathrm{kg} / \mathrm{ha}$ ) of different soybean varieties tested on light soil for three years each at Parbhani, Amrawati and Jalgaon location during kharif, 2007-08 to 2009-

\begin{tabular}{|l|c|c|c|c|}
\hline \multirow{2}{*}{ Varieties } & \multicolumn{4}{|c|}{ Seed yield (kg/ha) } \\
\cline { 2 - 5 } & $\begin{array}{c}\text { Parbhani } \\
(\mathbf{3})^{*}\end{array}$ & $\begin{array}{c}\text { Amrawati } \\
\mathbf{( 3 )}\end{array}$ & $\begin{array}{c}\text { Jalgaon } \\
(\mathbf{3})^{*}\end{array}$ & $\begin{array}{c}\text { *ocation pooled } \\
(\mathbf{9})\end{array}$ \\
\hline DS 228 & 1685 & 1406 & 1853 & 1648 \\
\hline JS 335 & 2094 & 1124 & 1720 & 1646 \\
\hline MACS 450 & 1968 & 1301 & 1788 & 1686 \\
\hline TAMS 38 & 1631 & 1226 & 1475 & 1444 \\
\hline TAMS 98-21 & 1891 & 1151 & 2107 & 1717 \\
\hline MAUS 32 & 1776 & 1554 & 1814 & 1581 \\
\hline MAUS 71 & 2016 & 1242 & 1800 & 1686 \\
\hline MAUS 47 & 1935 & 1367 & 1633 & 1645 \\
\hline SE \pm & 43.90 & 47.90 & 49.16 & 127.40 \\
\hline CD at 5 \% & 94.15 & 102.73 & 105.44 & 273.25 \\
\hline Grand Mean & 1875 & 1296 & 1774 & 1632 \\
\hline
\end{tabular}

*Figures in parenthesis indicate number of trials 
Table.2 Pooled analysis of seed yield $(\mathrm{kg} / \mathrm{ha}$ ) of different soybean varieties tested on medium type of soil for three years each at Parbhani, Amrawati and Jalgaon location during kharif, 2007-

08 to $2009-10$

\begin{tabular}{|c|c|c|c|c|}
\hline \multirow[t]{2}{*}{ Varieties } & \multicolumn{4}{|c|}{ Seed yield (kg/ha) } \\
\hline & $\begin{array}{c}\text { Parbhani } \\
\text { (3)* }\end{array}$ & $\underset{\text { (3) }}{\text { Amrawati }}$ & $\begin{array}{l}\text { Jalgaon } \\
\text { (3) }\end{array}$ & $\begin{array}{l}\text { Location pooled } \\
\text { (9) }\end{array}$ \\
\hline DS 228 & 2060 & 1364 & 1990 & 1805 \\
\hline JS 335 & 2322 & 1496 & 1904 & 1907 \\
\hline MACS 450 & 2105 & 1637 & 1885 & 1875 \\
\hline TAMS 38 & 1943 & 1487 & 1802 & 1744 \\
\hline TAMS 98-21 & 2140 & 1268 & 2289 & 1899 \\
\hline MAUS 32 & 2090 & 1036 & 1745 & 1624 \\
\hline MAUS 71 & 2432 & 1519 & 1955 & 1968 \\
\hline MAUS 47 & 1977 & 1187 & 1810 & 1658 \\
\hline SE \pm & 49.24 & 49.24 & 47.90 & 119.72 \\
\hline CD at $5 \%$ & 105.60 & 105.60 & 102.73 & 256.77 \\
\hline Grand Mean & 2134 & 1374 & 1923 & 1810 \\
\hline
\end{tabular}

*Figures in parenthesis indicate number of trials

Table.3 Pooled analysis of seed yield $(\mathrm{kg} / \mathrm{ha})$ of different soybean varieties tested on heavy type of soil for three years each at Parbhani, Amrawati and Jalgaon location during kharif, 2007-08 to 2009-10

\begin{tabular}{|c|c|c|c|c|}
\hline \multirow[t]{2}{*}{ Varieties } & \multicolumn{4}{|c|}{ Seed yield (kg/ha) } \\
\hline & $\begin{array}{c}\text { Parbhani } \\
(\text { (3)* }\end{array}$ & $\begin{array}{c}\text { Amrawati } \\
\text { (3) }\end{array}$ & $\begin{array}{c}\text { Jalgaon } \\
\text { (3) }\end{array}$ & $\begin{array}{c}\text { Location pooled } \\
\text { (9) }\end{array}$ \\
\hline DS 228 & 1968 & 1171 & 2270 & 1803 \\
\hline JS 335 & 2196 & 1413 & 2083 & 1897 \\
\hline MACS 450 & 2232 & 1335 & 2069 & 1879 \\
\hline TAMS 38 & 2141 & 1620 & 1960 & 1907 \\
\hline TAMS 98-21 & 2194 & 1363 & 2449 & 2002 \\
\hline MAUS 32 & 2499 & 1290 & 2167 & 1985 \\
\hline MAUS 71 & 2658 & 1163 & 2151 & 1991 \\
\hline MAUS 47 & 2090 & 1300 & 1919 & 1770 \\
\hline $\mathbf{S E}_{ \pm}$ & 47.53 & 49.24 & 49.35 & 136.11 \\
\hline CD at $5 \%$ & 101.95 & 105.60 & 105.84 & 291.92 \\
\hline Grand Mean & 2247 & 1332 & 2134 & 1904 \\
\hline
\end{tabular}

*Figures in parenthesis indicate number of trials 
Table.4 Mean seed yield ( $\mathrm{kg} / \mathrm{ha}$ ) of different soybean varieties tested on light, medium and heavy type of soil for three years each at Parbhani, Amrawati and Jalgaon location during kharif, 2007-08 to 2009-10

\begin{tabular}{|l|c|c|c|c|}
\hline \multirow{2}{*}{ Varieties } & \multicolumn{4}{|c|}{ Mean seed yield (kg/ha) } \\
\cline { 2 - 5 } & $\begin{array}{c}\text { Light soil } \\
(\mathbf{9 )}\end{array}$ & $\begin{array}{c}\text { Medium soil } \\
\text { (9) }\end{array}$ & $\begin{array}{c}\text { Heavy soil } \\
(\mathbf{9})\end{array}$ & $\begin{array}{c}\text { Mean } \\
(\mathbf{2 7})\end{array}$ \\
\hline DS 228 & 1648 & 1805 & 1803 & $\mathbf{1 7 5 2}$ \\
\hline JS 335 & 1646 & 1907 & 1897 & $\mathbf{1 8 1 6}$ \\
\hline MACS 450 & 1686 & 1875 & 1879 & $\mathbf{1 8 1 3}$ \\
\hline TAMS 38 & 1444 & 1744 & 1907 & $\mathbf{1 6 9 8}$ \\
\hline TAMS 98-21 & 1717 & 1899 & 2002 & $\mathbf{1 8 7 2}$ \\
\hline MAUS 32 & 1581 & 1624 & 1985 & $\mathbf{1 7 3 0}$ \\
\hline MAUS 71 & 1686 & 1968 & 1991 & $\mathbf{1 8 8 1}$ \\
\hline MAUS 47 & 1645 & 1658 & 1770 & $\mathbf{1 6 9 1}$ \\
\hline SE+ & 127.40 & 119.72 & 136.11 & \\
\hline CD at 5 \% & 273.25 & 256.77 & 291.92 & \\
\hline Grand Mean & 1632 & 1810 & 1904 & \\
\hline
\end{tabular}

*Figures in parenthesis indicate number of trials

In medium type of soil, the variety MAUS 71 $(2432 \mathrm{~kg} / \mathrm{ha})$ at Parbhani, MACS 450 (1637 $\mathrm{kg} / \mathrm{ha}$ ) at Amrawati and TAMS 98-21 (2289 $\mathrm{kg} / \mathrm{ha}$ ) recorded highest seed yield on an average of three trials conducted each at Parbhani, Amrawati and Jalgaon during 20072009. On pooled basis across the locations, the variety MAUS $71(1968 \mathrm{~kg} / \mathrm{ha})$ recorded highest seed yield followed by JS 335 (1907 $\mathrm{kg} / \mathrm{ha}$ ) and TAMS 98-21 (1899 kg/ha) (Table 2).

In heavy type of soil, on an average of three trials conducted during 2007-2009 at Parbhani, Amravati and Jalgaon location, the variety MAUS $71(2658 \mathrm{~kg} / \mathrm{ha})$ at Parbhani, TAMS $38(1620 \mathrm{~kg} / \mathrm{ha})$ at Amrawati and TAMS $98-21 \quad(2449 \mathrm{~kg} / \mathrm{ha})$ at Jalgaon recorded highest seed yield.

On pooled basis on an average of nine trials conducted across the locations, the variety TAMS 98-21(2002 kg/ha) recorded highest seed yield followed by MAUS 71 (1991 $\mathrm{kg} / \mathrm{ha})$ and MAUS 32 (1998 kg/ha), respectively (Table 3 ). On an average of twenty seven trials conducted across the soil types in light, medium and heavy soil and locations at Parbhani, Amrawati and Jalgaon for three years (nine trials at each location) during 2007-2008 to 2009-2010, the variety MAUS $71 \quad(1881.7 \mathrm{~kg} / \mathrm{ha})$ ranked first followed by in light and heavy soil, whereas, the variety MAUS 71 ranked first in medium type of soil.

On an average of twenty seven trials conducted during three years, in light, medium and heavy soil at the same location across the soil types, the variety MAUS 71 ranked first $(1881 \mathrm{~kg} / \mathrm{ha})$ followed by TAMS 98-21 (1872 kg/ha). The yield levels of JS 335 (1816 kg/ha) and MACS 450 (1813 $\mathrm{kg} / \mathrm{ha}$ ) was found almost at par (Table 4).

On the basis of present study, it can be concluded that the soybean variety TAMS 9821 is suitable for light and heavy soils whereas variety MAUS 71 is suitable for medium soil. Variety MAUS 71 has proved better performance irrespective of soil types with wider adoptability in Maharashtra state. 


\section{References}

Agarwal D K, S M Hussain, R Ramteke, V S Bhatia and Srivastava S K. 2010. Soybean Varieties of India, Directorate of Soybean Research, Indore, Madhya Pradesh, India, Pp 47.

Anonymous. 2005. Improved Soybean Varieties of India. National Research Centre for Soybean, Indore, Madhya Anonymous. 2012. Annual Report 2012-13, Directorate of Soybean Research, Indore, Madhya Pradesh.
Hans Kok, Dale L. Fjell and Gary L. Kilgore.1997. Seedbed Preparation and Planting Practices In Soybean Production Handbook, Kansas State University, United States Department of Agriculture Cooperating. Pp 8.

Samra J S and Ramachandra K S. 2009. Soybean Based Farming Systems for Improving Livelihood of Rainfed Areas, Policy paper-I, National Rainfed Area Authority, Ministry of Agriculture, Government of India, New Delhi. Pp 27.

\section{How to cite this article:}

Baig, K. S., D. G. More and Pandagale, A. D. 2020. Identification of Suitable Varieties of Soybean for Various Soil Types in Different Climatic Conditions. Int.J.Curr.Microbiol.App.Sci. 9(10): 1824-1828. doi: https://doi.org/10.20546/ijcmas.2020.910.222 